\title{
ASSESSING THE RELATIONSHIP AMONG SERVICE QUALITY DIMENSIONS IN HIGHER EDUCATION INSTITUTION AND STUDENT SATISFACTION BY APPLYING THE SERVQUAL MODEL
}

\author{
Shaista Kamal Khan \\ Assistant Professor, \\ Department of Business Administration, Jinnah University for Women, \\ Sindh, Pakistan \\ Email: shaistakamalkhan@gmail.com

\section{Tabassum Azra Siddiqui} \\ Assistant Professor, \\ Department of Education, Jinnah University for Women, \\ Sindh, Pakistan \\ Email: tabassumazra2017@gmail.com \\ Madiha Rais \\ Lecturer, \\ Department of Business Administration, Jinnah University for Women, \\ Sindh, Pakistan \\ Email: madiharais2016@gmail.com
}

\begin{abstract}
The aim of the paper is to assessing the relationship among service quality dimensions in higher education institutions and student satisfaction by applying the SERVQUAL model (tangibility, responsiveness, empathy, reliability and assurance). Furthermore examine the major purpose of service quality dimensions in higher education institution of Karachi, Pakistan. The data were collected based on SERVQUAL instrument on LIKERT scale, by distributing from 100 questionnaires to convenient selected undergraduate in higher education institutes of Karachi. The findings show that assurance has substantial impact on student satisfaction and rest of the variables has low impact on dependent variable which is student satisfaction. This research has some limitation the first is the sample size of this study is not that much enormous second limitation is due to short time period this study has not covered all higher education institutes of Pakistan. The quality of education in under developing countries is a serious problem. In order to improve this situation it is necessary to take serious action and capitalize in quality system and tools for upgrading. Especially in
\end{abstract}


Pakistan the education sector is not giving the standard education as per the expectation of the students so, it is important to analyse this serious issue.

\section{KEYWORDS}

Tangibility, Responsiveness, Empathy, Reliability, Assurance, SERVQUAL, Service Quality, Consumer Satisfaction.

\section{INTRODUCTION}

This is obvious that higher education contributes essential character in attaining economic progress. Currently economic move towards higher education role has more highlighted noted by Đonlagić, \& Fazlić, in (2015) and to enhance the ultra-modern and to being competitive of undertaking research projects should be intensify by higher education to strongly attached to real sector. Another research done by Abdullah, in (2016) mentioned that service sectors are participating key role in multiple nation of economy. In current environment of competition, quality service is to consider the major factor of success, and various analysis mentioned that the strongest competitive mode presently molding marketing and business master plan is quality of service.

The student's satisfaction towards higher education of service quality can be identified by the area of which the needs of students and their expectations are met, presently estimated by higher education of service quality. Another author defines service quality as matching customer expectation and further define by Philip Crosby, (1979) that it is conformance to identifications. Kanakana, (2014) further stated that quality owns both aspects of "what" and "how", so functional and technical both the qualities are essential to meet expectations of customers. Apparently by this quality of definition in which defines how customers identifies and measures just in time. In today's environment of competitiveness among institutions in which students have multiple alternatives accessible for them, components that give educational organizations to admire and keep students seriously must be studied. In future those academies of higher education want to attain edge of competitiveness, May necessary to start discovering for efficient and attractive options to admire, retain and to encourage the strong relationship with academy's students researched by (Hasan et al, 2009). Education is the most important part of human life. It is to be given at the right time and properly. But in this globally changing environment it is just to be considering as source of making money. Infrastructure and academic staff does not fulfil all the requirement of the students which leads to negative image of the institution and negative word of mouth which results the student's withdrawal. Fee structures are high but the assurance, reliability, tangibility, responsiveness and empathy are at very low level (Đonlagić, \& Fazlić, in (2015). This problem also affecting our country because students are approaching international universities which are far better than our national universities. 
This research is being conducted for try to resolve these gaps among higher education and student's expectation and their needs and to find out possible results (Kanakana, 2014). This study would be essential for those institutions who want to analyze the student's satisfactions level and to retain them after getting results. It will also help institutions to maintain the image and create positive word of mouth that will result of higher rank among various institutions and universities by higher education commission. By implementation of finding the higher education institution can increase the number of admission and also provide the quality of education that will be compete all over the world. This research is very significant due to it is going to analyze the level of service quality and level of student satisfaction. The recent study is the creation of viable model that will explain the influence of service quality on satisfaction of students. This study is applied on Higher Education Institutes to analyze the satisfaction of students towards their academic staff. This nature of study does not conduct earlier in Karachi, Pakistan therefore; this issue has been selected for research.

\section{LITERATURE REVIEW}

The literature review for current study is focused on many factors to find out the service quality of higher education such as reliability, assurance, empathy, tangibility, responsiveness and student satisfaction. The framework of the study is explained in this chapter, in order to provide a theoretical basis and understanding

\section{Service quality}

We can define the service quality is a behavior that is related to the satisfaction. The base of quality of service on the analysis of satisfaction and dissatisfaction that is measure by the difference among the current performance and expectation of customer related to service quality (Tariq et al, 2013).The concept of service quality very different from the quality of physical goods because of the unique nature such as perishability, inseparability, intangibility and variability. As per Kotler (2014) the service quality is an action of presentation that one person can offer to other which is principally untouched and does not outcome of ownership transfer (Pathmini, 2016). The idea of quality of education is not very old and now this is not well-built field of study. There is not a terminology for this purpose the term "quality of education" is explain by verity of way by different authors. The idea of quality of education has taken from corporate sector, as these definitions are the evidence such as: quality in education, value adding in education, defect free education system; meet to consumer's (students) expectation with education. International linkage, economic funding and liberalization and increasing competitive environment are the main causes for the importance of quality concept in higher education (Priyan \&Rohan, 2010).

\section{Service Quality Model}

According to research, related to customer behavior customer do not observe service 
quality in a one-dimensional means he or she critic multiple factors associated to the context of particular service. The service quality model or dimensions are identified by pioneering research of Parsu Parasuraman, Valarie Zeithaml and Leonard Berry. These researchers identified five specific dimensions of quality service and scale of measurement of service quality that is applicable verity of service contexts. These are the following dimension which is the drivers of service quality along with the scale of measurement that is called SERVQUAL (Parasuraman, Zeithaml \& Leonard Berry, 2010).

\section{Reliability}

The factor of reliability consists of components that focus on the capability for the provision of promised service on time, perfectly and faithfully. It is also related to the capability to accomplish promises, and the enthusiasm to provide the solution to the problems with a supportive and confident attitude. Further Kotler, et al, (2014) gave an explanation regarding the need of talking and helping customers satisfy their needs, because they are the sole cause for the establishment of a company's durability. Here the customers are students and company is an educational institution. So, the satisfaction of the customers happens when one's knowledge of a service offering meets the expectations (Cina, C., 1989). Reliability is precedent of customer satisfaction and in this study it means student satisfaction. In most of this literature (Parasuraman,et al.,(1998), Waugh (2001), Jusoh et al., (2004), Shaari (2014), Koni. A. et al., (2013)), it is shown that importance of the effect of reliability as a precedent of service quality to increase the student satisfaction in education sector and customer satisfaction in other sectors. In case of services, reliability means the level at which the services are foolproof. Parasuraman et al. (1988), focused that reliability is the potential to supply the promised service on time error-freely and devotedly.

\section{Assurance}

Every organization educates their personnel's in an efficient way so that they can satisfy their students through their sympathy, empathy, efficient connection and controlling activities etc. (Janardhana Gundla Palli \& Rajasekhar Mamilla, 2012). The progression of quality assurance in educational sectors is long standing because they evaluate their whole process through many level $\mathrm{s}$ and ways just to give satisfaction to their students by giving that features and that quality which they desire in education.(Miroiu Adrian et al, 2007,p.5).

Those educational institutes are grown and develop high which gives more importance to quality and in return they create loyal students and staff members, low loss in bad economic conditions, can demand high investment and high independency in policy making. There are many educational institutions which are facing high turnover because their employees and students think that other higher educational institutions 
give better quality related to this institution. (John C. Friend-Pereira et al, 2003). According to John C. Friend-et al, 2003, like business sector educational sector also face high demand as well as high pressure by the society about quality relating services. These demands became problem for those higher education institution, which didn't have great institutional structure, not have high finance \& means and didn't create their brand name, not only this it also has competition with national and international educational sectors.

\section{Empathy}

For creating empathic connection, teachers do work with their students and through this they can get highest satisfaction from their students. Empathy is a power through which you can understand and share others notion and emotions. According to Franco \& Cristina, 2003, Empathy means to pay attention to others and to taking fully part in indulging the feelings of others. Not only this but when you give fully attention to others so at that time you forget your own feelings by understanding others that show real empathy. (Emanuela Maria AVRAM).

Empathy is also an inner element of a person's appearance, strong connection and at some situation it is a clear view of a person in the front of empathic person. Here the clear view of a person not means that both the person shows everything at the front of others without hiding anything. It needs great capability of a person to recognize the feelings of others with the same sense. (Emanuela Maria AVRAM).Empathy and sympathy both are different from each other's. Empathy means understanding others feeling by recognizing own capability while sympathy means acknowledge others hardship and providing comfort to them. (Ferdinando de Muro, 2005).

According to Emanuela Maria AVRAM, in higher education there is close connection between students and teachers as students are transferring their message and teacher is easily receiving student's messages and communicates with them. There is two way growth and development relation between teachers and students because an empathic teacher can recognize the feelings, emotions and area of study interest so that his students can make their projects by their own and through his efforts he can able to make and maintain trust and believe.

Empathy is a prediction to identify the emotions, observations, thinking, and mindset of other people. Empathy has two functions which are performing by empathic teachers, one is predicting and other is connecting with the students by both ways orally or non- orally. (J.P. Guilford). Emanuela Maria AVRAM illustrate that it is essential for teachers to build up the knowledge and concentration of their students at their studying time so that they can accomplish their life relating goals. 


\section{Responsiveness}

The definition of responsiveness by M.Ahsan et al, 2010, the responsiveness is that at what level your institutional staff members are ready to deliver services to their student. According to Tariq Khalil Bharwana et al, 2013, the staff members are always ready to assist and give service to students, whenever they are confuse in anything and need help. The possibility and range of delivering services are varying sector to sector (Asubonteng, McCleary and Swan, 1996). Responsiveness is the concentration in giving timely services to the students when they want. (Zeithaml et al.1990). The height of customer's satisfaction is increase by the staff member's enthusiastic working at any time without showing any unwillingness attitude to them. (Parasuraman et al., 1988). Customers are happy when they get individual attention toward service providers as well as when staff members are considering students problems so student's level of satisfaction increases. (Kumar et al., 2009).

\section{Tanbibles}

The factor of tangibles of services quality deals with the physical appearance of facilities in education sector. It is necessary to maintain an obvious communication of information in the education procedure with the existence of equipment and facilities like well-furnished laboratories, properly up-to-date library with textbooks, reference books and other searching stuff; latest technological facilities, a complete and extensive information system and also the useful facilities like sports and recreation centers. Levitt (1981) states further that the large portion of tangibles will cut down the risk when it is attempted to be in communication regarding services with prospective customers. McDougall and Snetsinger (1990) stated the definition of tangibles as the level at which the service can give a pure visible picture. They further examined the definition and communicated that has both a physical and mental element. Previous researches were more related to the physical elements because researchers were more involved in the investigation and analysis of customer before buying a service. The mental element is related to the capability of customers to understand mentally what they will get if they buy the service. Here the customers are students. The characteristic of tangibles emphasizes more on capability to conceptualize the service. By realizing the level of service tangibility, organizations can know their competitive position in the market. Here organizations mean education sectors.

\section{Students satisfaction}

According to Tariq et al (2013) we can define customer satisfaction by varies ways. It is "the emotion $\mathrm{n}$ feeling of happiness after using of any product". On the other side customer satisfaction is the answer of achievement of needs. According to ACSI (American Customer Satisfaction Index) that "Satisfaction of customer is greater against quality pull than price pull and value pull. From the interpretation of many 
researcher and also observation that satisfaction is feeling and judgment what is got as against the expectation or wishes that is result of purchase and repurchase (Aramstrong \& Kotler, 1996; Tariq et al, 2013). In recent years higher education institutions are very concerned about the improvement of service quality, educational and teaching standard. The University is the source of higher education where students achieved many of chances to explore their career skills and personal growth. The quality of education the quality is the most dominant factor which is evaluated by student/customer that is judge on the bases on perception vs expectation (Janardhana and Rajasekhar, 2012).

\section{Conceptual framework}

In order to study the influence of assurance, responsiveness, empathy, reliability and tangibility on student satisfaction related to the higher education. A conceptual framework built on the basis of the literature review and find out five service quality dimensions with related to satisfaction. The independent variables of service quality that impact on consumer satisfaction are five variables such as tangibility, reliability, empathy, assurance and responsiveness. The dependent variable is student satisfaction. The relationship between dependent and independent variables represents in the following figure 1.

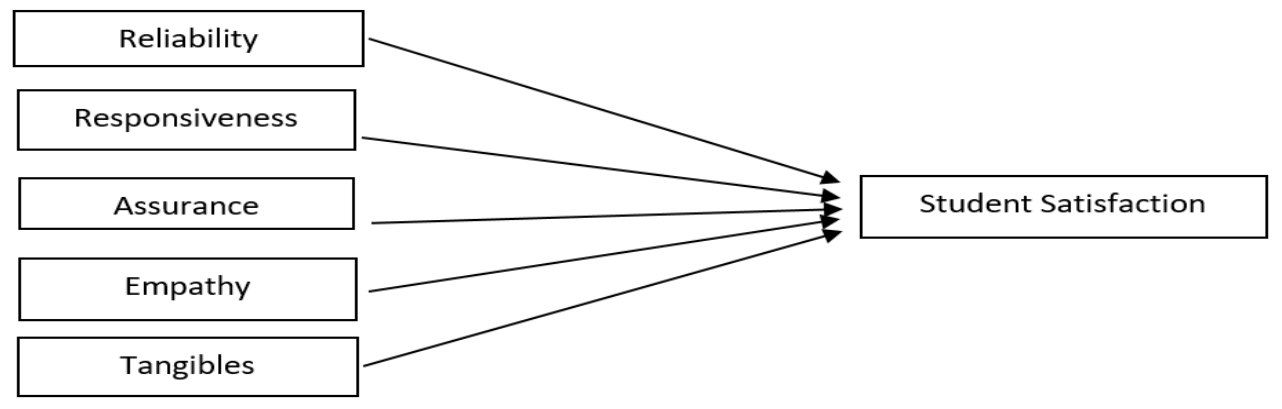

Figure 1: Conceptual Framework

\section{RESEARCH OBJECTIVE}

1. To examine the relationship among service quality dimensions and students 'satisfaction.

2. To examine the relationship among tangibles and students 'satisfaction.

3. To examine the relationship among reliability and students 'satisfaction.

4. To examine the relationship among empathy and students 'satisfaction.

5. To examine the relationship among assurance and students 'satisfaction.

6 . To examine the relationship among responsiveness and students 'satisfaction. 


\section{RESEARCH QUESTIONS}

1. What is the influence of service quality dimensions on students 'satisfaction?

2. What is the influence of tangibles on students 'satisfaction?

3. What is the influence of reliability on students 'satisfaction?

4. What is the influence of empathy on students 'satisfaction?

5. What is the influence of assurance on students 'satisfaction?

6. What is the influence of responsiveness on students 'satisfaction?

\section{RESEARCH HYPOTHESES}

1. Service quality has an impact on students 'satisfaction.

2. Tangibles have an impact on students 'satisfaction.

3. Reliability has an impact on students 'satisfaction.

4. Empathy has an impact on students 'satisfaction.

5. Assurance has an impact on students 'satisfaction.

6. Responsiveness has an impact on students 'satisfaction.

\section{RESEARCH METHODOLOGY}

The selection of right research methodology is important for the research because that will effect on the relevant information take out from the data. The basic nature of this research is quantitative and according to the purpose of this study is to explore the determinants of service quality. It is based on systematic relationship and investigation.

\section{Statistical Technique}

Five statistical techniques that will apply on data such as reliability test, multiple regression, sample adequacy, confirmatory and exploratory factor analysis. For find out the relationship between dependent and independent variables regression analysis will be carried out and reliability of the data by reliability test, sample adequacy explains the adequacy of the sample size.

\section{Sample size}

This study's data will be gathered through sample size of 100 respondents who belongs to Karachi, Pakistan. The respondents were the students of Higher Education Institutes as this research have especially applied on the universities.

\section{Questionnaire Design}

For the primary data collection, the self-administered or close ended questionnaire will be used. It is consists of six parts. The first part analysis the connection between tangibles and student satisfaction, second part measure the relationship between empathy and student satisfaction. Third part finds out the association between responsiveness and student satisfaction. Forth part identify the relationship between assurance and student satisfaction. Part fifth explore the relationship between 
reliability and student satisfaction.

\section{Measurement Scale}

Likert Five-point scale will be use from part one to five of the questionnaire, with 1 show "strongly disagree" and 5 means "strongly agree". By this measurement scale we will collect the primary data to explore the relationship between service quality and student satisfaction.

\section{DATA ANALYSIS AND RESULTS}

The given below statics represent the model summary and Multiple regression that denotes by $\mathrm{R}$ estimates the true variable and forecast values by applying linear function.

Table 1: Model Summary

\begin{tabular}{ccccc}
\hline Model & $\mathbf{R}$ & $\begin{array}{c}\mathbf{R} \\
\text { Square }\end{array}$ & $\begin{array}{c}\text { Adjusted R } \\
\text { Square }\end{array}$ & $\begin{array}{c}\text { Std. Error of the } \\
\text { Estimate }\end{array}$ \\
\hline 1 & $.713^{\mathrm{a}}$ & .509 & .483 & .61187 \\
\hline
\end{tabular}

a. Predictors: (Constant), Tangible Total, Reliability Total, Assurance Total, Empathy Total, Responsiveness Total

The value of $\mathrm{R}$ given above in table is somehow close to 1 that indicates a minimum association among dependent and independent variables. The R-square specified by coefficient of determination that shows entire variation among independent variable. The $\mathrm{R}$ value is .713 denotes the degree of correlation. $\mathrm{R}^{2}$ value is 0.509 indicates approx. $50.9 \%$ of variant are described among independent variables.

Table 2: ANOVA ${ }^{\mathrm{a}}$

\begin{tabular}{|c|c|c|c|c|c|}
\hline Sum of Squares & df & $\begin{array}{c}\text { Mean } \\
\text { Square }\end{array}$ & $\mathbf{F}$ & Sig. & \\
\hline Regression & 36.433 & 5 & 7.287 & 19.463 & $.000^{\mathrm{b}}$ \\
\hline Residual & 35.192 & 94 & .374 & & \\
\hline Total & 71.625 & 99 & & & \\
\hline
\end{tabular}

a. Dependent Variable: Student Satisfaction Total

b. Predictors: (Constant), Tangible Total, Reliability Total, Assurance Total, Empathy Total, Responsiveness Total

The above AVOVA table present F-statistics which is 19.463. According to many scholars the F-statistics value should be greater than 3.5 then it would be consider as model is significant at the level of 0.05 significance level. So, the above F-statistics of this table is 19.463 which is greater than 3.5 therefore, this model for this research is statistically consequential as less than 0.05 like as $\mathrm{P}(0.000)<(0.05)$. 


\begin{tabular}{|c|c|c|c|c|c|c|}
\hline \multicolumn{7}{|c|}{ 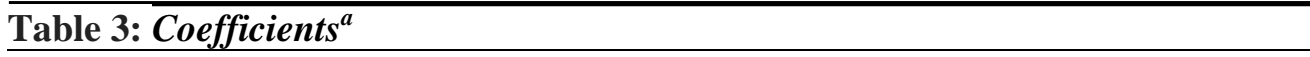 } \\
\hline \multirow{9}{*}{$\begin{array}{l}\text { Model } \\
1\end{array}$} & & \multicolumn{2}{|c|}{$\begin{array}{l}\text { Unstandardized } \\
\text { Coefficients }\end{array}$} & \multirow{3}{*}{$\begin{array}{c}\text { Standardized } \\
\text { Coefficients } \\
\text { Beta }\end{array}$} & \multirow[b]{3}{*}{$\mathrm{t}$} & \multirow[b]{3}{*}{ Sig. } \\
\hline & & & Std. & & & \\
\hline & & B & Error & & & \\
\hline & (Constant) & .478 & .361 & & 1.325 & .188 \\
\hline & Assurance Total & .246 & .119 & .198 & 2.056 & .043 \\
\hline & Responsiveness Total & .230 & .117 & .240 & 1.970 & .050 \\
\hline & Empathy Total & .180 & .103 & .198 & 1.750 & .083 \\
\hline & Reliability Total & .060 & .119 & .051 & .499 & .619 \\
\hline & Tangible Total & .155 & .106 & .164 & 1.464 & .147 \\
\hline
\end{tabular}

a. Dependent Variable: Student Satisfaction Total

Table no. 11.1.3 indicated the coefficient result and its significance. While all the variables are constant the coefficient statistics shows how considerably dependent variable differ with independent variable. The entire statistics represent that among five variables (Assurance, Responsiveness, Empathy, Reliability and Tangible) only two hypothesis that are Assurance and Responsiveness are accepted and rest of the hypothesis are rejected. Assurance $p$ value is 0.43 and responsiveness $p$ value is 0.52 that is less than 0.05. So, this is concluded that assurance and responsiveness has significant impact on student satisfaction.

\section{Table 4: Reliability Statistics}

\section{Cronbach's Alpha N of Items .895 6}

In this table we can see that Cronbach's alpha is 0.895, which indicates a high level of internal consistency for our scale. The value associated with Alpha in this set of reliability statistics is said to be accepted and the conclusion draw from this data is reliable to understand and forecast. And the model is refer to be consider as good.

\section{CONCLUSION}

In this research SERVQUAL instrument has been used to obtain five service quality dimensions of reliability, responsiveness, assurance, empathy and tangibles. The result of reliability test Cronbach's Alpha is 0.895 which indicate high level of internal consistency for overall expectations and perceptions. There are five hypothesis which is tested through SPSS and in the result only two hypothesis (Assurance and Responsiveness) are truly significance and accepted while other three hypothesis (Reliability, Tangibles and Empathy) are not accepted in this test which means that Assurance and Responsiveness have high influence on Student satisfaction while other 
three variables have lowest influence on Student Satisfaction. Service quality has significance relation with student satisfaction so student satisfaction can be increase by improving the service quality of the higher education. Higher education focus on reliability, tangibility and empathy to satisfy and retain the students.

After completed the objective of this research successfully. There may be limitation of this research. Sample size is not that much huge because of limited time. Due to limited resources this research focused on just one institution belong to Karachi. Only Students will be the respondent because of time shortage. The results are applicable only to graduates and may not be generalizable to post graduates.

\section{RECOMMENDATIONS}

This research should be expand and include all higher education institutes (public or private).

In this research we have focus on student satisfaction. For further research we can focus on teacher and other expectation and perception.

Insufficient funds, mismanagement, and lack of modern infrastructure, among others, negatively affect efficient services in developing countries higher educations; it should be adequate and manage to gain student satisfaction.

\section{REFERENCES}

Abdullah, F. (2006). Measuring service quality in higher education: HEdPERF versus SERVPERF. Marketing Intelligence \& Planning, 24(1), 31-47.

Avram, E. M. (2011). Student Satisfaction In Higher Education And Empathy In Relationship With Them. Holistic Marketing Management Journal, 1(1), 61-64.

Bharwana, T. K., Bashir, M., \& Mohsin, M. (2013). Impact of service quality on customers' satisfaction: A study from service sector especially private colleges of Faisalabad, Punjab, Pakistan. International Journal of Scientific and Research Publications, 3(5), 1-7.

Ezeokoli, R. N., \& Ayodele, K. O. (2014). Dimensions of service quality encountered by students on sustainability of higher education in Nigeria. Dimensions, 4(6).

Hasan, H. F. A., Ilias, A., Rahman, R. A., \& Razak, M. Z. A. (2009). Service quality and student satisfaction: A case study at private higher education institutions. International Business Research, 1(3), 163.

Janardhana\& Rajasekhar (2012), Students' Opinions of Service Quality in the Field of Higher Education. Vol.3, No.4, 430-438

Kanakana, M. G. (2014, January). Assessing service quality in higher education using the SERVQUAL tool. In International Conference on Industrial Engineering and Operations Management, Bali, Indonesia (pp. 68-74).

Malik, M. E., Danish, R. Q., \& Usman, A. (2010). The impact of service quality on students' satisfaction in higher education Institutes of Punjab. Journal of Management 
Research, 2(2), 1.

Negricea, C. I., Edu, T., \& Avram, E. M. (2012). Analysis of casual links and relationship between higher education quality, Student satisfaction and intention, Based on development of conceptual model. Romanian Economic and Business Review, 7(2), 47.

Palli, J. G., \& Mamilla, R. (2012). Students' opinions of service quality in the field of higher education. Creative Education, 3(04), 430.

Pathmini, M. G. S ( 2016) . Impact of Service Reliability on Student Satisfaction in newly Established Public Sector Universities (NEPUs) in Sri Lanka: Perspective 5(1).

Pathmini, M. G. S. (2016). Impact of Service Reliability on Student Satisfaction in Newly Established Public Sector Universities in Sri Lanka: Perspective on Undergraduates in Management Faculties. International Journal on Global Business Management \& Research, 5(1), 11.

Selvakumar, J. J. (2016). Impact of service quality on customer satisfaction in public sector and private sector banks. Purushartha: A Journal of Management Ethics and Spirituality, 8(1).

Witte, J., Huisman, J., \& Purser, L. (2009). European higher education reforms in the context of the bologna process: How did we get here, where are we and where are we going?. Higher education to, 2030, 205-229. 